(c) Group of authors, 2019

UDC 616.8-07

DOI - https://doi.org/10.14300/mnnc.2019.14121

ISSN - 2073-8137

\title{
MOLECULAR BIOMARKERS OF COGNITIVE IMPAIRMENT IN ISCHEMIC STROKE
}

Efimova M. Yu. 1, 2, Ivanova N. E. ${ }^{2}$, Alekseeva T. M. ', Ivanov A. Yu. ${ }^{3}$, Tereshin A. E. ${ }^{2}$, Makarov A. O. ${ }^{2}$, Reshetnik D. A. ${ }^{2}$

${ }^{1}$ National Medical Research Center named after V. A. Almazov, Saint-Petersburg, Russian Federation

2 Nikolaev Hospital, Saint-Petersburg, Peterhof, Russian Federation

${ }^{3}$ Saint-Petersburg State Pediatric Medical University, Russian Federation

\section{МОАЕКУАЯРНЫЕ БИОМАРКЕРЫ КОГНИТИВНЫХ НАРУШЕНИЙ ПРИ ИШЕМИЧЕСКОМ ИНСУАЬТЕ}

\author{
М. Ю. Ефимова ', 2 , Н. Е. Иванова ', Т. М. Алексеева ${ }^{1}$, \\ А. Ю. Иванов ${ }^{3}$, А. Е. Терешин ${ }^{2}$, А. О. Макаров ${ }^{2}$, А. А. Решетник ${ }^{2}$ \\ ${ }^{1}$ Национальный меАицинский исслеАовательский центр им. В. А. Алмазова, \\ Санкт-Петербург, Российская ФеАерация \\ ${ }^{2}$ Николаевская больница, Санкт-Петербург, Петергоф, Российская Фелерация \\ ${ }^{3}$ Санкт-Петербургский госуАарственный пеАиатрический \\ меАицинский университет, Российская ФеАерация
}

At the review systematize modern ideas about biomarkers of cognitive impairment in ischemic stroke were performed. The metabolic changes underlying the ischemic cascade were combined into three basic processes: excitotoxicity, oxidative stress, and inflammation. Studies of the possible relationship between key metabolites and mediators of acute ischemic stroke and the state of higher cortical functions are analyzed. The search for sensitive and specific biomarkers of cognitive impairment will make it possible to predict the rehabilitation potential and will promote the earliest possible start of cognitive rehabilitation measures. Besides, it will enable the development of modern methods of drug correction and prevention of vascular dementia.

Keywords: higher cortical functions, cognitive impairment, biomarkers, ischemic stroke, excitotoxicity, oxidative stress, inflammation

Систематизированы современные представления о биомаркерах когнитивных нарушений при ишемическом инсульте. Метаболические изменения, лежащие в основе ишемического каскада, объединены в три базовых процесса: эксайтотоксичность, оксидативный стресс и воспаление. Проанализированы исследования, в которых определяется взаимосвязь ключевых метаболитов и медиаторов острого периода ишемического инсульта с состоянием высших корковых функций. Поиск чувствительных и специфичных биомаркеров когнитивных нарушений позволит прогнозировать реабилитационный потенциал и будет способствовать максимально раннему началу мероприятий когнитивной реабилитации. Кроме того, определяется возможность разработки патофизиологически обоснованных методов медикаментозной коррекции и профилактики сосудистой деменции.

Ключевые слова: высшие корковые функции, когнитивные нарушения, биомаркеры, ишемический инсульт, эксайтотоксичность, оксидативный стресс, воспаление

For citation: Efimova M. Yu., Ivanova N. E., Alekseeva T. M., Ivanov A. Yu., Tereshin A. E., Makarov A. O., Reshetnik D. A. MOLECULAR BIOMARKERS OF COGNITIVE IMPAIRMENT IN ISCHEMIC STROKE. Medical News of North Caucasus. 2019;14(3):567-571. DOI - https://doi.org/10.14300/mnnc.2019.14121

Для цитирования: Ефимова М. Ю., Иванова Н. Е., Алексеева Т. М., Иванов А. Ю., Терешин А. Е., Макаров А. О., РешетнИк Д. А. МОЛЕКУЛЯРНЫЕ БИОМАРКЕРЫ КОГНИТИВНЫХ НАРУШЕНИЙ ПРИ ИШЕМИЧЕСКОМ ИНСУЛЬТЕ. Медицинский вестник Северного Кавказа. 2019;14(3):567-571. DOI - https://doi.org/10.14300/mnnc.2019.14121

$\begin{array}{ll}\text { BDNF } & - \text { Brain Neurotrophic Factor } \\ \text { D-serine } & - \text { the right-rotating optical isomer of serine } \\ \text { ESR } & \text { - Erythrocyte Sedimentation Rate } \\ \text { IL } & - \text { Interleukin }\end{array}$

- Erythrocyte Sedimentation Rate

- Interleukin
NMDA-receptors- N-methyl-D-aspartate receptors NR2-peptide - N-terminal domain of NMDA receptor RAGE-receptor - Advanced Glycation End Products receptor TNF-a - Tumor Necrosis Factor 
P oststroke cognitive disorders are moderately expressed in $37-71 \%$ of observations, and in 4-40\% of cases reach the degree of dementia [1]. At the same time, they are pathogenetically and clinically heterogeneous, which affects their curability and prognosis [2]. The study of cognitive status by traditional neuropsychological methods in the acute period of stroke is difficult due to the severity of patients' condition, misinterpretation of testing results is possible in patients with apathy (20-25\% of observations), depression (30-40\% of observations), anxiety disorders [3]. All this dictates the need to search for sensitive and specific biomarkers to predict the development of poststroke cognitive impairments. M. Riverol and co-authors have combined the criteria inherent in the ideal biomarker: specificity for the disease, ability to reflect the severity of its course and effectiveness of treatment, economic accessibility, and minimal invasiveness $[4,5]$. Metabolomics is a new branch of knowledge acting by measuring large arrays of metabolites with low molecular weight in biological media (liqueur, blood plasma, urine) and tissues of the body [6]. To date, data on the links of metabolic changes with cerebral ischemia has been accumulated.

Exaytotoxicity markers. Excitotoxicity is a universal phenomenon of the second nerve cell damage caused by hyperproduction or reduction of the reuptake rate of excitation neurotransmitters [7]. The essential, exciting transmitter is glutamate. In a healthy organism, glutamate provides a realization of many cognitive processes, among which are training and consolidation of memory trail. Persistent activation of NMDA-receptors is a universal link to the pathogenesis of both acute cerebral ischemia and dementia of various etiologies $[8,9]$. Data on the dynamics of glutamate concentration in the blood plasma in the acute stroke period are contradictory. Some authors reported an increase in glutamate levels [10]; others noted that there was no increase in its concentration, explaining this phenomenon with low permeability for the hematoencephalic barrier mediator [11]. There was revealed a rise in the level of glutamate-glutamine precursor in the acute period of ischemic stroke, and its degree correlated with the severity of cognitive impairments [10]. This allowed suggesting glutamine as a potential biomarker of poststroke cognitive deficiency. It was revealed that a fragment of NMDA-receptors NR2-peptide in the first hours of stroke is fragmented by serine protease and enters the blood plasma, where it is possible to determine it by rapid methods [12].

$D$-serine, involved in the norm in the implementation of higher cortical functions, is a coagonist of NMDA-receptors. However, in cerebral ischemia, excessive formation of $D$-serine from $L$-serine with the help of serine racemase enzyme aggravates excitotoxicity, and some authors consider inhibition of serine racemase as a promising mechanism of neuroprotection, which allows, among other things, to reduce the severity of cognitive deficiency [13].

Oxidative stress markers. Oxidative stress-cell damage due to oxidation processes involving reactive oxygen forms $[6,14]$. As a result, increased concentrations of oxidation products are recorded in the plasma. The mechanisms of lipid peroxidation during acute ischemic stroke were studied in a sufficiently deep way; a study involving 3726 patients showed that a high level of oxidized lipoproteins of low yield correlates with a pronounced cognitive deficiency [15]. According to other data, the estimation of the dynamics of oxidized modifications of proteins (the primary ketone and aldehyde derivatives of dinitrophenylhydrazones) can also serve as a biomarker for the prediction of poststroke neuropsycho- logical impairments [16]. The study of the concentration of malondialdehyde and 8-hydroxydeoxyhanosine - common products of lipid and deoxyribonucleic acid oxidation - demonstrated a significant excess of their level in observations with cognitive impairments [17]. A more detailed assessment of their role as biomarkers of cognitive deficiency is required. One of the key mediators of impairment of the integrity of the hematoencephalic barrier and hemorrhagic transformation is matrix metalloproteinase-9. Its transition to the active form as a result of the proteolytic splitting of the predecessor molecule is carried out due to oxidative stress [6]. As a result of studies of brain tissue, and a liqueur of patients who have vascular dementia, a significant increase in the level of this mediator was found [18]. The works on the relationship between the concentration of matrix metalloproteinase- 9 and poststroke cognitive deficiency are few. However, the analysis of 558 observations with ischemic stroke revealed that its high levels on the first day after cerebral circulation impairment correlate with impairments of higher cortical functions [19]. Probably, the excess activity of matrix metalloproteinase- 9 contributes to proteolytic degradation of the hematoencephalic barrier and subsequent diffuse damage to the white matter of the brain [20]. Hyperhomocysteinemia is not only a recognized risk factor for ischemic stroke but also a marker of brain endothelial damage during acute ischemia $[6,21]$. The connection between the level of homocysteine in acute stroke and the risk of vascular dementia is proved [22]. An important role is given to post-translational modification of proteins called homocysteinylation, and impairments of formation of astrocytic contacts with capillaries, which leads to ionic and osmotic imbalance [22]. Folic acid, remethylating homocysteine in methionine, was proposed as a biomarker of ischemic stroke [23]. The effect of its concentration in the acute ischemia period on the further state of cognitive functions is not fully determined, but it is proved that its deficiency in the poststroke period reliably correlates with the deficiency of higher cortical functions [22, 24].

Markers of inflammation. Inflammatory response induced by impaired cerebral circulation causes an increase in the production of pro-inflammatory cytokines activating indolamine-2,3-dioxygenase; this enzyme causes a decrease in concentrations of tryptophan AA and kynurenine hyperproduction [6]. Growth in the concentration of kynurenine metabolites and exhaustion of tryptophan is a marker of adverse prognosis of ischemic stroke. Low tryptophan level is associated with a significant cognitive deficit in Alzheimer's disease [25]. A similar study conducted with the participation of stroke patients showed a link between increased kynurenine to tryptophan ratio and the degree of severity of poststroke cognitive impairment [26]. A possible explanation of this phenomenon is hyperproduction of toxic metabolites of kynurenine, such as quinoline, hydroxyanthranyl, and kynurenic acid. These compounds can interact with NMDA-receptors, which confirms the unity and interdependence of the fundamental processes of the ischemic cascade. Attempts of pharmacological correction of kynurenine metabolism for the prevention of impairments of higher cortical functions are carried out $[26,27]$. The inflammatory response also modifies the metabolism of phospholipids: phosphatidylethanolamine, phosphatidylcholine, and lysophosphatidylcholine [6]. Their plasma concentration is reduced in chronic cerebral ischemia, as well as in Alzheimer's disease, but with acute ischemic damage it may increase [28]. A stable relationship between the level of lysophosphatidylcholine (18: 2) and the degree of severity of poststroke cognitive deficiency was described [9], but further in-depth studies 
are needed to recommend this metabolite for use as a biomarker. Regulation of the inflammation process is carried out by the whole ensemble of cytokines. It was revealed that low level of $\mathrm{IL}-10$ and $\mathrm{IL}-6$, as well as the dominance of IL-1 $\beta$ in liqueur are predictors of stable cognitive status; high level of IL-10 in liqueur, as well as prevalence of IL-10 over IL-1 $\beta$ in plasma is a predictor of positive dynamics; prevalence of IL-1 $\beta$ over IL-10 in plasma is a marker of possible progression of cognitive impairments [29]. Another study showed that high levels of IL-8 in plasma were independently associated with early formation of poststroke cognitive deficiency, and elevated IL-12 concentrations were associated with gradual cognitive decline [29]. These compounds, however, can only be used as biomarkers in combination with other indicators due to their low specificity. Several studies have shown a link between poststroke cognitive deficiency and the level of C-reactive protein, as well as ESR [28, 30]. Prognostically unfavorable role of high concentration of rheumatoid factor in acute ischemia for formation of subsequent cognitive deficiency was also determined [31]. The hypothesis about the effect of inflammation intensity on higher cortical functions needs to be further checked; it seems promising to develop preventive measures aimed at this link of pathogenesis.

The biochemical commonality of poststroke cognitive impairments and Alzheimer's disease. Often stroke is the cause of decompensation of a longrunning neurodegenerative process, and poststroke cognitive impairments are nothing but a manifestation of Alzheimer's disease [1]. There is a certain commonality of the pathogenesis of these diseases: on the one hand, risk factors of cerebral circulation contribute to amyloidogenesis, on the other hand, amyloid angiopathy inherent in Alzheimer's disease in itself increases the risk of stroke [2]. It is proved that the plasma level of amyloid $\beta 40$ increases in vascular cognitive impairments; the correlation between the rise in its concentration in blood plasma during the acute stroke period and the degree of severity of neurological impairments was revealed [32]. All this makes it possible to consider $\beta$-amyloid as a potential biomarker of the development of mixed cognitive impairments during the acute stroke period. It was established that the level of amyloid $\beta 40$ in liqueur negatively correlates with the state of higher cortical functions [33]. It was suggested that the fraction $\beta 40$ is related to vasomotor impairments in acute ischemia, while amyloid $\beta 42$ is specific to neurodegenerative processes [34].

Neurospecific biomarkers. Determination of concentration of neurospecific biomarkers in different biological media is a promising direction in early diagnosis of ischemic stroke. Acute ischemic damage to the brain leads to leakage of neurospecific proteins into liqueur and further into plasma. One of the most studied is protein $\mathrm{S} 100 \mathrm{~B}$, belonging to the group of calcium-binding proteins [35]. The concentration of S100B increases in plasma and liqueur in the first hours after stroke. Some researchers suggested the mechanism of protein participation in the development of cognitive deficiency by activating the RAGE-receptor of the final products of glycosylation and the subsequent increase of the expression of TNF- $\alpha$ [35]. Attempts were made to determine the relationship between the concentration of S100B during carotid endarterectomy and the subsequent cognitive deficiency, but the degree of correlation did not reach the expected level [35]. In the experiment, transgenic mice with increased production of $\mathrm{S} 100 \mathrm{~B}$ were characterized by a decrease in short-term memory, impairment of visual and spatial gnosis, and attention [36]. As a fundamentally new biomarker of impairments of higher cortical functions can be considered protein S100A9: it was revealed that it's blocking in observations with Alzheimer's disease contributed to the partial restoration of cognitive abilities [37].

Further study of the S100A9 in the context of ischemic stroke is required. Neuronspecific enolase is a tissue isoform of an enzyme involved in glycolysis processes [38]. It is assumed that measuring the level of this enzyme can be informative in terms of predicting poststroke cognitive impairments, but it is necessary to have a deeper understanding of its kinetics in acute ischemia period. Considerable attention is paid to the determination of levels of neurotrophic factors. In the observations with severe craniocerebral injury, the relationship between rehabilitation potential and the concentration in plasma of the brain neurotrophic factor (BDNF) was found [39]. The introduction of exogenous BDNF in ischemic stroke, Parkinson's disease, and Alzheimer's disease, according to some reports, improves the cognitive status of patients; however, information on the direction of the dynamics of the postischemic expression of BDNF is contradictory.

Other potential biomarkers. The independent predictor of the formation of postischemic cognitive impairments is, according to the results of many studies, the precursor of vasopressin copeptin [40]. A-1antitrypsin and plasminogen-1 activator inhibitor are proposed as markers of vascular dementia [30]. There was an increase in the ratio of $\alpha$-1-antitrypsin to creatinine in urine in patients with postoperative cognitive deficiency [41]. The possibility of application of 6-sulfaoxymelatonin and other melatonin metabolites as biomarkers of impairment of higher cortical functions is being studied. A link was demonstrated between low triiodothyronine levels in the acute period and cognitive deficiency a month after a vascular disaster [42]. Attempts are made to use polymorphism of specific genes, such as presenilin and apolipoprotein E, involved in the excretion of amyloid, to predict poststroke cognitive impairments [30]. Finally, the evaluation of peripheral microRNA profiles, non-coding small molecules regulating gene expression, seems to be a promising method. It was found that microRNK-31, $-93,-143$, and -146 a expression profile can serve as a non-invasive biomarker for the diagnosis of Alzheimer's disease [30]. In one of the studies, microRNC-132 was proposed as a predictor of adverse cognitive outcomes in ischemic stroke [43].

Conclusions. Thus, to date, there is no sufficiently sensitive and specific biomarker of cognitive impairments in ischemic stroke. However, a large number of modern studies on this issue, the variety of compounds proposed for solving this problem, allow us to hope for future success. Application of a complex of several biomarkers, development of panels to determine the degree of risk of cognitive deficiency, a competent combination of biochemical technologies with the interpretation of results of neuropsychological testing will increase the accuracy of predicting poststroke cognitive impairments.

\section{Disclosures:}

The authors declare no conflict of interest. 


\section{References}

1. Naumenko A. A., Vakhnina N. V. Alzheimer's disease under the mask of stroke. Nevrologiya, neiropsikhiatriya, psikhosomatika. 2016;8(2):100-106. https://doi.org/10.14412/2074-2711-2016-2-100-106

2. Cai Z., Wang C., He W., Tu H., Tang Z. [et al.] Cerebral small vessel disease and Alzheimer's disease. Clin. Intervt. Aging. 2015;10:1695-1704. https://doi.org/10.2147/cia.s90871

3. Fanning J. P., Wong A. A., Fraser J. F. The epidemiology of silent brain infarction: a systematic review of population-based cohorts. BMC Medicine. 2014;12:119. https://doi.org/10.1186/preaccept-3620022701268369

4. Hsieh Y. C., Seshadri S., Chung W. T., Hsieh F. I., Hsu H. [et al.] Association between genetic variant on chromosome 12p13 and stroke survival and recurrence: a one year prospective study in Taiwan. J. Biomed. Sci. 2012;3:19. https://doi.org/10.1186/1423-0127-19-1

5. Riverol M., Lopez O. Biomarkers in Alzheimer's disease. Front. Neurol. 2011:2:46.

https://doi.org/10.3389/fneur.2011.00046

6. Sidorov E., Sanghera D. K., Vanamala J. K. P. Biomarker for ischemic stroke using metabolome: a clinician perspective. Journal of Stroke. 2019;21(1):31-41. https://doi.org/10.5853/jos.2018.03454

7. Rueda C. B., Llorente-Folch I., Traba J., Amigo I., Gonzalez-Sanchez P. [et al.] Glutamate excitotoxicity and Ca2+-regulation of respiration: Role of the Ca2+ activated mitochondrial transporters (CaMCs). Biochim. Biophys. Acta. 2016;1857(8):1158-1166

https://doi.org/10.1016/j.bbabio.2016.04.394

8. Danysz W., Parsons C. G., Mobius H.-J., Stoffler A., Quack G. Neuroprotective and symptomatological action of memantine relevant for Alzheimer's disease - a unified glutamatergic hypothesis on the mechanism of action. Neurotox. Res. 2000;2:85-97. https://doi.org/10.1007/bf03033787

9. Sonni S. Two generations with stroke and cognitive decline. Stroke. 2016:4:27-32.

https://doi.org/10.1093/med/9780190497255.003.0005

10. Liu M., Zhou K., Li H., Dong X., Tan G. [et al.] Potential of serum metabolites for diagnosing post-stroke cognitive impairment. Mol. Biosyst. 2015;11:3287-3296. https://doi. org/10.1039/c5mb00470e

11. Ding X., Liu R., Li W., Ni H., Liu Y. [et al.] A metabonomic investigation on the biochemical perturbation in post-stroke patients with depressive disorder (PSD). Metab. Brain. Dis. 2016;31:279-287 https://doi.org/10.1007/s11011-015-9748-z

12. Dambinova S. A., Aliev K. T., Bondarenko E. V., Ponomarev G. V., Skoromets A. A. [et al.] The biomarkers of cerebral ischemia as a new method for the validation of the efficacy of cytoprotective therapy. Zhurnal nevrologii i psihiatrii. 2017;5:62-67. https://doi.org/10.1007/s11055-018-0707-0

13. Mustafa A. K., Ahmad A. S., Zeynalov E., Gazi S. K., Sikka G. [et al.] Serine racemase deletion protects against cerebral ischemia and excitotoxicity. J. Neurosci. 2010;30(4):14131416. https://doi.org/10.1523/jneurosci.4297-09.2010

14. Fonteh A. N., Harrington R. J., Tsai A., Liao P., Harrington M. G. Free amino acid and dipeptide changes in the body fluids from Alzheimer's disease subjects. Amino Acids. 2007;32:213-224 https://doi.org/10.1007/s00726-006-0409-8

15. Wang A., Liu J., Meng $X$, Li J., Wang $\mathrm{H}$. [et al.] Association between oxidized low-density lipoprotein and cognitive impairment in patients with ischemic stroke. Eur. J. Neurol. 2018;25(1):185-191. https://doi.org/10.1111/ene.13497

16. Domínguez C., Delgado P., Vilches A., Martín-Gallán P. Ribó M. [et al.] Oxidative stress after thrombolysis-induced reperfusion in human stroke. Stroke. 2010;4(41):653-660. https://doi.org/10.1161/strokeaha.109.571935

17. Liu Z., Liu Y., Tu X., Shen H., Qiu H. [et al.] High Serum Levels of Malondialdehyde and 8-OHdG are both Associated with Early Cognitive Impairment in Patients with Acute Ischaemic Stroke. Sci. Rep. 2017;7(1):9493. https://doi.org/10.1038/s41598-017-09988-3

18. Adair J. C., Charlie J., Dencoff J. E., Kaye J. A., Quinn J. F. [et al.] Measurement of gelatinase B (MMP-9) in the cerebrospinal fluid of patients with vascular dementia and Alzheimer disease. Stroke. 2004;35:159-162. https://doi.org/10.1161/01.str.0000127420.10990.76

19. Zhong C., Bu X., Xu T., Guo L., Wang X. [et al.] Serum Matrix Metalloproteinase-9 and Cognitive Impairment After Acute Ischemic Stroke. J. Am. Heart. Assoc. 2018;7(1):e007776. https://doi.org/10.1161/jaha.117.007776

20. Wardlaw J. Doubal F Armitage P Chappell F Carpenter T. [et al.] Lacunar stroke is associated with diffuse bloodbrain barrier dysfunction. Ann. Neurol. 2009;65:194-202. https://doi.org/10.1002/ana.21549

21. Lonn E., Yusuf S., Arnold M. J., Sheridan P., Pogue J. [et al.] Homocysteine lowering with folic acid and B vitamins in vascular disease. N. Engl. J. Med. 2006;354:1567-1577. https://doi.org/10.1016/s0749-4041(08)70686-9

22. Price B. R., Wilcock D. M., Weekman E. M. Hyperhomocysteinemia as a Risk Factor for Vascular Contributions to Cognitive Impairment and Dementia. Front. Aging. Neurosci. 2018;10:350. https://doi.org/10.3389/fnagi.2018.00350

23. Qian L., Ding L., Cheng L., Zhu X., Zhao H. [et al.] Early biomarkers for post-stroke cognitive impairment. J. Neurol. 2012;259:2111-2118 https://doi.org/10.1007/s00415-012-6465-y

24. Jiang Z., Sun J., Liang Q., Cai Y., Li S. [et al.] A metabonomic approach applied to predict patients with cerebral infarction. Talanta. 2011;84:298-304. https://doi.org/10.1016/j.talanta.2011.01.015

25. Pascoe M. C., Linden T. Folate and MMA predict cognitive impairment in elderly stroke survivors: A cross sectional study. Psychiatry Res. 2017;243:49-52. https://doi.org/10.1016/j.psychres.2016.06.008

26. Gulaj E., Pawlak K., Bien B., Pawlak D. Kynurenine and its metabolites in Alzheimer's disease patients. Adv. Med. Sci. 2010;55:204-211.

https://doi.org/10.2478/v10039-010-0023-6

27. Skoromets A. A., Dambinova S. A., Granstrem O. K., Skoromets A. P. Skoromets T. A. [et al.] The fundamental importance of new biomarkers of brain ischemia. Medicinskij akademicheskij zhurnal. 2009;9(4):107-112. https://doi.org/10.1007/s11055-018-0707-0

28. Gold A. B., Herrmann N., Swardfager W., Black S. E., Aviv R. I. [et al.] The relationship between indoleamine 2,3-dioxygenase activity and post-stroke cognitive impairment. J. Neuroinflammation. 2011:8:17 https://doi.org/10.1186/1742-2094-8-17

29. Kulesh A. A., Drobakha B. E., Kuklina E. M., Shestakov B. B. The cognitive trajectory of patients in rehabilitation period of ischemic stroke: the role of neuroinflammation and cerebral structural factors. Kazanskii meditsinskii zhurnal. 2017;4(98):513-518. https://doi org/10 17750/kmi2017-513

30. Mijajlović M. D., Pavlović A., Brainin M., Heiss W. D., Quinn TJ [et al.] Post-stroke dementia - a comprehensive review. BMC Med. 2017;15(1):11. https://doi org/10.1186/s12916-017-0779-7

31. Narasimhalu K., Lee J., Leong Y. L., Ma L., De Silva D. A. [et al.] Inflammatory markers and their association with post stroke cognitive decline. Int. J. Stroke. 2015;10:513-518. https://doi.org/10.1111/ijs.12001

32. Zhu Z., Chen L., Guo D., Zhong C., Zhong C. [et al.] Serum rheumatoid factor levels at acute phase of ischemic stroke are associated with poststroke cognitive impairment. Eur. J. Neurol. 2018;25(1):185-191. https://doi.org/10.1016/j.jstrokecerebrovasdis. 2018.12.049

33. Park L., Zhou P., Koizumi K., El Jamal S., Previti M. L. [et al.] Brain and circulating levels of $A \beta 1-40$ differentially contribute to vasomotor dysfunction in the mouse brain. Stroke. 2013; 44 (1): 198-204 https://doi.org/10.1161/strokeaha.112.670976

34. Kulesh A. A., Drobakha V. E., Kuklina E. M., Shestakov V. V. Amyloid-beta 40 as a biomarker of cognitive impairment in acute ischemic stroke. Byulleten' sibirskoj mediciny. 2017:16(3):79-86. https://doi.org/10.20538/1682-0363-2017-3-79-86

35. Moulin S., Leys D., Schraen-Maschke S., Bombois S., Mendyk A. M. [et al.] $A \beta 1-40$ and $A \beta 1-42$ plasmatic levels in stroke: influence of pre - existing cognitive status and stroke characteristics. Curr. Alzheimer Res. 2015;14(6):686-694. https://doi.org/10.2174/1567205012666151027141730

36. Rezaei O., Pakdaman H., Gharehgozli K., Simani L., Vahedian-Azimi A. [et al.] A new concept in neurocritical care. Iran Journal Neurol. 2017;16:83-89. https://doi.org/10.1007/springerreference 137991

37. Sahlein D. H. Heyer E J. Rampersad $\bar{A}$, Winfree C.J. Solomon R. A. [et al.] Failure of intraoperative jugular bulb S-100B and neuron-specific enolase sampling to predict cognitive injury after carotid endarterectomy. Neurosurgery. 2003;53(6):1243-1250. https://doi.org/10.1227/01.neu.0000093493.16850.11 
38. Lebedeva E. V., Gorokhov A. S., Schastnyy E. D., Repin A. N., Simutkin G. G. [et al.] Time course of cognitive dysfunction and biochemical marker of CNS lesions $\mathrm{S} 100 \mathrm{~B}$ in coronary artery bypass graft. Byulleten' sibirskoj mediciny. 2018:17(2):72-84.

https://doi.org/10.20538/1682-0363-2018-4-72-84

39. Golubev A. M., Kuzovlev A. N., Antonova V. V., Zakharchenko V. E., Petrova M. V. [et al.] Molecular biomarkers for prediction of neurological outcome after sudden circulatory arrest (review). General reanimatology. 2018;14(3):6881. https://doi.org/10.15360/1813-9779-2018-3-68-81

40. Avrushchenko M. S., Ostrova I. V. Postresuscitative changes of brainderived neurotrophic factor (BDNF) protein expression: association with neuronal death. General reanimatology. 2017;13(4):6-21.

https://doi.org/10.1016/j.resuscitation.2017.08.196
41. Ivkin A. A., Grigoriev E. V., Shukevich D. L. Diagnostics of cognitive dysfunction in patients in the intensive care wards. Vestnik anesteziologii i reanimatologii. 2018;15(3):47-55. https://doi.org/10.21292/2078-5658-2018-15-3-47-55

42. Chen H., Wu Y., Huang G., He W., He W. [et al.] Low tri-iodothyronine syndrome is associated with cognitive impairment in patients with acute ischemic stroke: a prospective cohort study. Am. J. Geriatr. Psychiatry. 2018;26(12):12221230. https://doi.org/10.1016/j.jagp.2018.07.007

43. Huang S., Zhao J., Huang D., Zhuo L., Liao S. [et al.] Serum miR-132 is a risk marker of post-stroke cognitive impairment. Neurosci. Lett. 2016;615:102-106. https://doi.org/10.1016/j.neulet.2016.01.028

\begin{abstract}
About authors: tel.: +79111395559; e-mail: atmspb@mail.ru

tel.: +79119111055; e-mail: alexey-iv@yandex.ru

tel.: +79818278785; e-mail: aet-spb@yandex.ru

tel.: +79043361100; e-mail: aomakarov@mail.ru

(C) Akter M., 2019

UDC 616.381-072.1.995.121

DOI - https://doi.org/10.14300/mnnc.2019.14142

ISSN - 2073-8137
\end{abstract}

Efimova Maria Yurevna, CMedSc, Assistant of Professor of the Department of neurology and psychiatry; neurologist of the Department of rehabilitation; tel.: +79052705565; e-mail: medice_levsha@mail.ru

Ivanova Natalia Evgenevna, MD, Professor, Chief researcher; tel.: +79112187149; e-mail: ivamel@yandex.ru

Alekseeva Tatyana Mihaylovna, MD, Associate Professor, Head of the Department of neurology and psychiatry;

Ivanov Aleksey Yurevich, MD, Professor of the Department of cardiovascular surgery;

Tereshin Alexey Evgenevich, CMedSc, Head of the Rehabilitation Department;

Makarov Artem Olegovich, CMedSc, Head of the Neurological Department № 2;

Reshetnik Dmitrii Aleksandrovich, MD, Chief physician; tel.: +78124097500; e-mail: rda1212@yandex.ru

\title{
EXTRACTION OF TEXTURE FEATURES FROM MEDICAL IMAGES: OSTEOARTHRITIS CASES REVIEW
}

Akter $M$.

University of Bedfordshire, Luton, United Kingdom

\section{ВЫАЕАЕНИЕ ТЕКСТУРНЫХ ОСОБЕННОСТЕЙ ААННЫХ ИЗ РЕНТГЕНОВСКИХ ИЗОБРАЖЕНИЙ ПРИ ОСТЕОАРТРОЗЕ}

\author{
М. Актер
}

\section{Университет БеАфорАшира, Аутон, Великобритания}

Texture features of osteoarthritis quantitatively represent patterns of interest in image analysis and interpretation in medicine. Texture features can widely vary so that the analysis can lead to interpretation errors and undesirable consequences. In such cases, finding of informative features becomes problematic. In medical imaging, the texture features of bones were useful for representing variations in patterns of pixel intensity, which were correlated with pathological changes. In this paper, we review existing approaches to extracting the texture features and conclude on usability, including machine learning.

Keywords: texture features, osteoarthritis, medical imaging, pattern recognition, machine learning

Точная визуализация и интерпретация рентгенологической картины текстуры остеоартроза представляет интерес в современных условиях. Особенности изменений текстуры костной ткани могут сильно варьировать, и поэтому проводимый компьютерный анализ может приводить к ошибкам в интерпретации данных и к неправильной постановке диагноза. В таких случаях поиск информативных признаков становится проблематичным. В медицинской визуализации особенности текстуры строения кости чрезвычайно важны для представления вариаций паттернов 